\title{
Crambe affected by biological and chemical seed treatments
}

\author{
Alex Júnior Cattanêoํㅜ José Renato Stangarlin ${ }^{1}$, Doglas Bassegio ${ }^{2 \star}$, Reginado Ferreira Santos ${ }^{1}$ \\ 1. Universidade Estadual do Oeste do Paraná - Departamento de Engenharia de Energia na Agricultura - Cascavel (PR), Brazil. \\ 2. Universidade Estadual Paulista “Júlio de Mesquita Filho" - Departamento de Produção e Melhoramento Vegetal - Botucatu \\ (SP), Brazil.
}

\begin{abstract}
Crambe has great potential for cultivation in tropical regions, but its biotic factors may be a limiting aspect for its production. Thus, we aimed in this study to assess the effect of pre-sowing seed treatments on seedling emergence, root system, production components, and oil. The experiment was conducted during two years in Cascavel, Paraná, Brazil. The experimental design consisted of randomized blocks with six treatments, including a control treatment (no treatment), biological treatments (Trichoderma asperellum and Bacillus subtilis), and chemical treatments (glutamic acid, thiamethoxam and zinc), with four replications. Emergence and growth crambe, as well as production components
\end{abstract}

and oil in the first year were higher due to the contrast in the agricultural years. In the first year, the chemical treatment with thiamethoxam stood out for emergency of plants. Seed treatments did not influence the growth of the aerial parts of the plants, but provided an increase in the root system, especially zinc. Biological (T. asperellum and B. subtilis) and chemical (thiamethoxam) seed treatments led to higher crambe yield when compared to the control treatment; however, the biological treatment with T. asperellum provided less oil.

Key words: Bacillus subtilis, Trichoderma asperellum, thiamethoxam, glutamic acid, zinc.

\section{INTRODUCTION}

Crambe abyssinica (Brassicaceae) is a winter crop with large potential to occupy idle areas in autumn and winter in tropical agricultural systems in Brazil due to its favorable agronomic characteristics and its oil, which can be used for manufacturing biodiesel. However, there is little technical information on crambe behavior in Brazil and even less data concerning its cultivation in western Paraná. There is also little information on factors that may limit its production, such as diseases.

In Brazil, Moers et al. (2012) observed the presence of the following fungi and bacteria in crambe seeds in western Paraná: Fusarium sp., Xanthomonas campestris pv. campestris, and Alternaria brassicae. Carneiro et al. (2009), Macagnan et al. (2010), and Pitol et al. (2010) also observed Alternaria sp. in other Brazilian regions.

In this sense, given the large number of diseases that can affect crambe crops, the use of control measures to minimize losses is essential. Among these measures, the use of resistant cultivars, pathogen-free seeds, and chemical treatments can guarantee healthier and more productive plants (Mertz et al. 2009).

Treatments with fungicides have long been used to protect seeds from fungal infections after sowing or to reduce the transmission of fungi from the infected seed to the plant shoot (Munkvold 2009). The application of chemicals prior to sowing has become a routine practice in Brazil with emphasis on the use of fungicides and insecticides even though it is not feasible, considering environmental aspects and possible effects on the inoculants used to provide biological nitrogen fixation. Furthermore, the overuse of these pesticides represents serious risks to the environment due to the persistence of residues.

Non-chemical methods are also used to manage plant diseases in certain crops. The biological seed treatment (microbiolization) with endophytic metabolites produced by different microorganisms inhibits a variety of agents that cause diseases and, therefore, represents a significant and unexplored source of agents for the biocontrol of plant 
diseases (Gunatilaka 2006). According to Ashraf and Foolad (2005), there are some beneficial bacteria and fungi, which can increase plant growth and development if applied to the seeds prior to planting. Another non-chemical method uses plant nutrition as a component of disease management (Hossain and Mian 2005). According to Haider et al. (2014), micronutrient management like the use of $\mathrm{Zn}, \mathrm{S}$, and $\mathrm{B}$ could be a good option for the management of Alternaria. Meena et al. (2015) demonstrated that deficiency of nutrients including $\mathrm{K}, \mathrm{S}, \mathrm{Zn}$, and $\mathrm{Cu}$ increases the Alternaria blight susceptibility on Brassica juncea plants because, when a plant becomes infected by Alternaria blight, its natural defenses might be triggered.

Thus, due to the large number of diseases affecting crambe in tropical conditions, the limited volume of scientific information, and the hypothesis that pre-sowing seed treatments contribute to increase crambe production, we aimed in this study to evaluate the influence of the treatment of crambe seeds during two years of cultivation on seedling emergence, root system, production components, grain yield, and oil.

\section{MATERIAL AND METHODS}

The experiment was conducted from June to October in 2012 and 2013. The area used for the experiments is located in the city of Cascavel, Paraná, Brazil, at lat $24^{\circ} 56^{\prime} 20,344^{\prime \prime} S$, long $53^{\circ} 30^{\prime} 54,668^{\prime \prime} \mathrm{W}$, and altitude of $718 \mathrm{~m}$. The area has been conducted in no-tillage system with the cultivation of soybean, corn, oats, beans, wheat, and canola.

Local soil is classified as Rhodic Hapludox (Red Latosol in the Brazilian classification) (Embrapa 2006). Prior to the experiment, we collected a soil sample $(0-20 \mathrm{~cm})$ whose contents were: $\mathrm{pH}$ in $\mathrm{CaCl}_{2}(0.01 \mathrm{M})$ of 5.26; $44.5 \mathrm{~g} \cdot \mathrm{kg}^{-1}$ of organic matter; $7.43 \mathrm{mg} \cdot \mathrm{dm}^{-3}$ of $\mathrm{P}$ (Mehlich-1); $0.53 \mathrm{cmol}_{\mathrm{c}} \cdot \mathrm{dm}^{-3}$ of K $\mathrm{K}^{+} ; 5.37 \mathrm{cmol} \cdot \mathrm{dm}^{-3}$ of $\mathrm{Ca}^{2+} ; 2.36 \mathrm{cmol}_{c} \cdot \mathrm{dm}^{-3}$ of $\mathrm{Mg}^{2+} ; 13.70 \mathrm{cmol}_{c} \cdot \mathrm{dm}^{-3}$ of cation exchange capacity (CEC); and $59 \%$ base saturation.

The local climate is classified as Cfa (subtropical climate), with average annual rainfall of approximately $1,800 \mathrm{~mm}$, no defined dry season, and occurrence of frosts during the winter. Figure 1 shows weather data concerning temperature and precipitation (July to October) in 2012 and 2013.

The experimental design used in this study consisted of randomized blocks with six treatments: control treatment (no treatment); biological treatments with Trichoderma asperellum SF 04 isolate in dispersible granule formulation (WG) (56 g i.a. $100 \mathrm{~kg}^{-1}$ seed); Bacillus subtilis $\left(5 \times 10^{9} \mathrm{ufc} \cdot \mathrm{mL}^{-1}\right.$, $200 \mathrm{~mL} \cdot 100 \mathrm{~kg}^{-1}$ seed); chemical treatments with glutamic acid (2\%), seaweed extract (1\% Ascophillum nodosum), cobalt $\left(13.7 \mathrm{~g} \cdot \mathrm{L}^{-1}\right)$, molybdenum $\left(137 \mathrm{~g} \cdot \mathrm{L}^{-1}\right)$, and manganese $\left(1.37 \mathrm{~g} \cdot \mathrm{L}^{-1}\right)$ in rates of $1,500 \mathrm{~mL} \cdot 100 \mathrm{~kg}^{-1}$ seed; thiamethoxam (350 g. $\mathrm{L}^{-1} / 70$ g i.a. $\cdot 100 \mathrm{~kg}^{-1}$ seed); and zinc (ajifol $\mathrm{Zn}$ ) (120 g.L $\mathrm{L}^{-1} / 96 \mathrm{~g} \cdot 100 \mathrm{~kg}^{-1}$ seed) with four replications. Seed treatments were prepared on the day of sowing. Each plot measured $4.05 \times 5.00 \mathrm{~m}\left(20.25 \mathrm{~m}^{2}\right)$.

Crambe sowing was performed on June 29, 2012 and July 9, 2013, in no-tillage system using the crambe cultivar FMS Brilhante, with the aid of a seeder-fertilizer machine (PST 3) with spacing of $0.45 \mathrm{~m}$ between rows, $0.03 \mathrm{~m}$ deep. The set of disc and ring employed was the same used for the sorghum crop (52-hole disc), which provided a sowing rate of $12 \mathrm{~kg} \cdot \mathrm{ha}^{-1}$ and approximately 100 plants per linear meter.

After approximately 15 days after emergence (DAE), in both years, we verified the attack of Diabrotica speciosa, which was controlled by using a 20-L backpack sprayer with $0.2 \mathrm{~L} \cdot \mathrm{ha}^{-1}$ thiamethoxam insecticide + lambda-cyhalothrin.

We carried out the estimation of the number of germinated seedlings per linear meter on the 7 th and 14th DAE, with the aid of a measuring tape. We always performed the measurements at the same location as the previous assessment. Plant height $(\mathrm{m})$, root volume $\left(\mathrm{cm}^{3}\right)$, and root dry mass $(\mathrm{g})$ assessments were held at flowering (45 DAE) in five plants per plot. In order to assess plant height, we used a measuring tape, whereas, for root volume, we used Archimedes' method. For the immersion of roots, we used a $50-\mathrm{mL}$ beaker and distilled water. For the root dry mass analysis, we used the same roots, which were weighed and placed in paper packages, then dried at $60{ }^{\circ} \mathrm{C}$ for a period of seven days.

Crambe harvest took place on October 20, 2012 and October 18, 2013. Harvesting and threshing were performed manually. As for the harvest, we disregarded $0.5 \mathrm{~m}$ on the edges and collected only $1 \mathrm{~m}^{2}$ per plot. After harvesting, we performed threshing and cleaning with the aid of screens and applied correction to $13 \%$ moisture (wet basis).

For the assessment of oil content, we performed Soxhlet extraction (IAL 2008) in laboratory conditions using petroleum ether solvent. The extraction was carried out using $2 \mathrm{~g}$ of ground seeds. By using this method, we were able to obtain the results of weight differences in percentage. 
We performed the analysis of variance (ANOVA) in a $2 \times 6$ factorial scheme. Averages were compared by means of Tukey's test $(\mathrm{p} \leq 0.05)$.

\section{RESULTS AND DISCUSSION}

Figure 1 shows that, despite higher precipitation during the experiment in 2013 (358 $\mathrm{mm}$ ) than in 2012 (266 $\mathrm{mm})$, the low temperature of $0{ }^{\circ} \mathrm{C}$ during the flowering and seed filling stages was decisive for the development of the crop since it is sensitive to low temperatures and frosts in the flowering stage (Pitol et al. 2010).

The interaction showed significant responses on emergence on the 7 th and 14 th DAE (Table 1). In what concerns to the germination of plants in the first week of experiment in 2012 (Table 2), the seed treatment with thiamethoxam provided higher emergence of plants (85 plants) in comparison to the ones treated with glutamic acid (65 plants), B. subtilis (74 plants), T. asperellum (74 plants), and the control treatment (60 plants). We observed a similar behavior in the second week, in which the treatment with thiamethoxam provided higher emergence (100 plants). In 2012, crambe germination was higher when chemical and/or biological
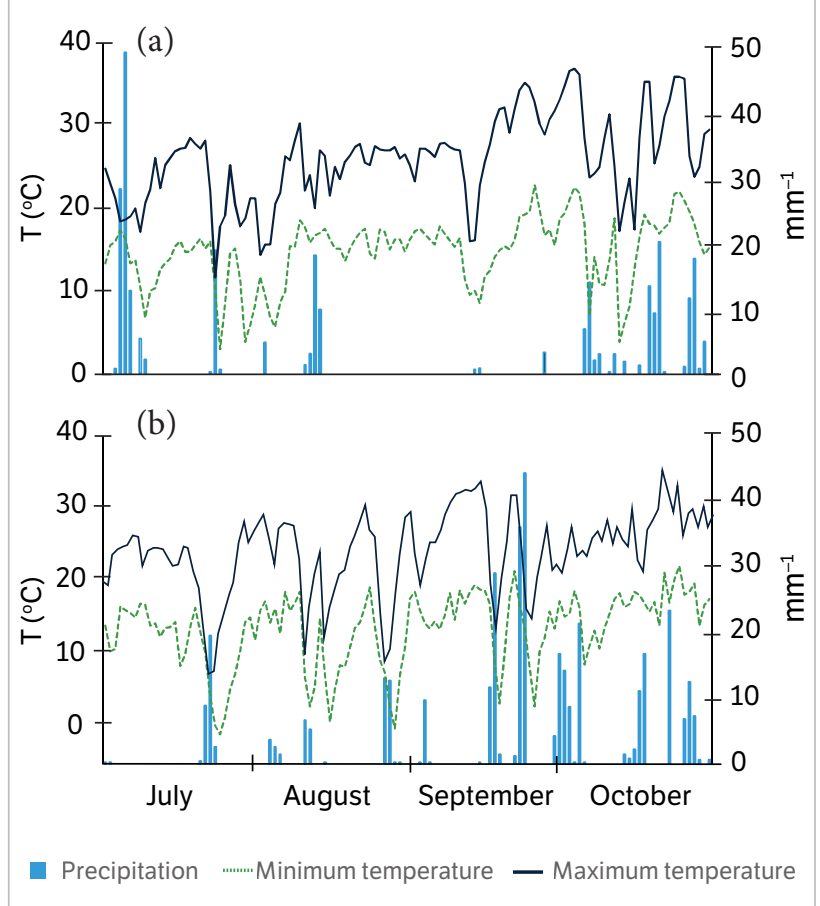

Figure 1. Monthly rain and average monthly temperatures in Cascavel, Paraná State, Brazil, from July to October: (a) 2012; (b) 2013. seed treatments were performed. One of the possible causes for this difference from the control treatment may be the incidence of fungi in the seeds, since they were not treated with fungicide. Hossen et al. (2014) also observed a higher percentage of germination when treating wheat with thiamethoxam. According to these authors, thiamethoxam accelerates the germination of seeds by stimulating the activity of enzymes, which causes more uniform stand and emergence of plants as well as better initial growth. Dubey and Singh (2013) observed that the combination Trichoderma virens + thiamethoxam increased seed germination. However, Cunha et al. (2015) did not observe effect of thiamethoxam on soybean germination.

Ludwig et al. (2014), at laboratory conditions in a biochemical oxygen demand (BOD) and germination chamber, observed that the chemical seed treatment with carbendazim did not affect germination and crambe seedling emergence on the seventh DAE. Maciel et al. (2014), also in a laboratory, found that the chemical seed treatments with pyraclostrobin + thiophanate, methyl + fipronil, carbendazim and carboxin + thiram did not affect the germination of crambe seedlings. Mertz et al. (2009), when applying biological and chemical treatments to soybean at field conditions, achieved higher emergence with the use of chemical treatments with carbendazim + thiram than with biological treatments with Trichoderma spp.

In what concerns to plant germination in the first week of experiment in 2013 (Table 2), the chemical treatments with glutamic acid (60 plants), thiamethoxam (58 plants), and the control treatment (63 plants) led to similar results, whose values are higher than that of the treatment with B. subtilis ( 47 plants). As for the second week of emergence, there was an increase in the treatment with glutamic acid (76 plants) in comparison to the treatments with B. subtilis (56 plants), zinc (57 plants), and the control treatment (63 plants). Oliveira et al. (2014) studied zinc-based seed treatments in Avena sativa L. and did not observe increase in germination and seed vigor. Yagi et al. (2006) also studied zinc and observed a reduction in the percentage of sorghum germination as rates were increased.

Plant height (Table 1) was not affected by the seed treatments; however, higher (8\%) plant height was observed in $2012(0.89 \mathrm{~m})$ than in $2013(0.82 \mathrm{~m})$, which is due to contrasting conditions of precipitation and temperature. In some cases, inoculation or treatment of seeds with bacteria 
can promote plant growth (Hafeez et al. 2004; Sharma and Johri 2003). Mattei et al. (2013), when studying the chemical treatment of seeds with carboxin + thiram in two crambe crops in a greenhouse, found negative effect of seed treatment on plant height at 14 and 21 DAE for both crops. Ludwig et al. (2014) observed larger plant height $(1.50 \mathrm{~m})$ in crambe plants treated with chemical fungicide (carbendazim) than in untreated plants $(1.18 \mathrm{~m})$. Araujo (2013), working with biological fungicide, did not observe increase in the height of corn, soybean, and cotton plants with the employment of a biological seed treatment with B. subtilis. Mertz et al. (2009) did not observe effect of seed treatments on the height of wheat plants.

Root dry mass and root volume (Table 2) benefited from the chemical treatment with zinc in 2012. Zinc is often deficient in Brazilian soils due to intensive use of land

Table 1. Emergence in one and two weeks, plant height, root dry mass, root volume, thousand grain weight, yield and oil of crambe according to seed treatments in $2012-2013$ agricultural years.

\begin{tabular}{|c|c|c|c|c|c|c|c|c|}
\hline Variation sources & $\begin{array}{c}1 \text { week } \\
\text { (plants per } \mathrm{m} \text { ) }\end{array}$ & $\begin{array}{c}2 \text { weeks } \\
\text { (plants per } \mathrm{m} \text { ) }\end{array}$ & $\begin{array}{l}\text { PH } \\
(\mathrm{m})\end{array}$ & $\begin{array}{l}\text { RDM } \\
\text { (g) }\end{array}$ & $\begin{array}{l}\text { RV } \\
\left(\mathrm{cm}^{3}\right)\end{array}$ & $\begin{array}{l}\text { TGW } \\
\text { (g) }\end{array}$ & $\begin{array}{c}\text { Yield } \\
\left(\mathbf{k g}^{-1} \mathrm{ha}^{-1}\right)\end{array}$ & $\begin{array}{l}\text { Oil } \\
\text { (\%) }\end{array}$ \\
\hline & \multicolumn{8}{|c|}{$\mathbf{S}$} \\
\hline Controla $^{a}$ & $62 \mathrm{bc}$ & $62 \mathrm{~d}$ & 0.87 & $0.66 b$ & $0.26 \mathrm{~b}$ & 6.17 & $1,231 b$ & $23.5 \mathrm{a}$ \\
\hline T. asperellum & $65 \mathrm{bc}$ & $78 \mathrm{~b}$ & 0.84 & $0.70 \mathrm{~b}$ & $0.24 b$ & 6.04 & $1,416 a$ & $21.4 \mathrm{~b}$ \\
\hline B. subtilis & $61 c$ & $70 \mathrm{c}$ & 0.84 & $0.73 \mathrm{~b}$ & $0.28 \mathrm{~b}$ & 6.22 & $1,411 a$ & $23.0 \mathrm{ab}$ \\
\hline Glutamic acid & $62 \mathrm{bc}$ & $78 \mathrm{~b}$ & 0.86 & $0.70 \mathrm{~b}$ & $0.30 \mathrm{~b}$ & 6.34 & $1,378 a b$ & $23.2 \mathrm{a}$ \\
\hline Thiamethoxam & $71 \mathrm{a}$ & $86 a$ & 0.87 & $0.72 \mathrm{~b}$ & $0.30 \mathrm{~b}$ & 6.01 & $1,457 a$ & $23.2 a b$ \\
\hline \multirow[t]{2}{*}{ Zinc } & $68 \mathrm{ab}$ & $72 b$ & 0.85 & $0.92 \mathrm{a}$ & $0.46 a$ & 6.24 & $1,346 a b$ & $22.1 \mathrm{ab}$ \\
\hline & \multicolumn{8}{|c|}{$\mathbf{Y}$} \\
\hline Mean (2012) & $73 a$ & $83 a$ & $0.89 a$ & $0.65 b$ & $0.35 a$ & $7.13 a$ & $1,604 \mathrm{a}$ & $25.1 \mathrm{a}$ \\
\hline Mean (2013) & $56 \mathrm{~b}$ & $66 \mathrm{~b}$ & $0.82 \mathrm{~b}$ & $0.83 a$ & $0.26 \mathrm{~b}$ & $5.21 b$ & $1,142 \mathrm{~b}$ & $20.4 b$ \\
\hline F-test & \multicolumn{8}{|c|}{ F-value } \\
\hline S & $7.85^{\star *}$ & $23.49^{* *}$ & $0.89^{\text {ns }}$ & $6.59^{* *}$ & $12.73^{* *}$ & $0.73^{\text {ns }}$ & $4.49^{* *}$ & $179.02^{* *}$ \\
\hline Y & $196.38^{* *}$ & $148.36^{* *}$ & $33.25^{\star *}$ & $40.87^{* *}$ & $23.94^{* *}$ & $255.13^{\star *}$ & $228.77^{* *}$ & $3.47^{\star}$ \\
\hline Interaction $\mathrm{S} \times \mathrm{Y}$ & $19.40^{* *}$ & $14.89^{* *}$ & $0.00^{\mathrm{ns}}$ & $8.40^{* *}$ & $4.57^{\star *}$ & $2.13^{\mathrm{ns}}$ & $2.20^{\mathrm{ns}}$ & $2.37^{\mathrm{ns}}$ \\
\hline
\end{tabular}

Without any treatment; ${ }^{*} \mathrm{p}<0.05$; ${ }^{* *} \mathrm{p}<0.01$; ns Not significant at $\mathrm{p}<0.05$. PH = Plant height; RDM = Root dry mass; RV = Root volume; TGW = thousand grain weight; $\mathrm{S}=$ Seed treatment; $\mathrm{Y}=$ Year.

Table 2. Agricultural years versus seed treatment interaction for seedling emergence in one and two weeks, root dry mass and root volume in crambe.

\begin{tabular}{|c|c|c|c|c|c|c|}
\hline \multirow{2}{*}{ Year } & \multicolumn{6}{|c|}{ Seed treatment } \\
\hline & Controla & T. asperellum & B. subtilis & Glutamic acid & Thiamethoxam & Zine \\
\hline \multicolumn{7}{|c|}{1 week (plants per $\mathrm{m}$ ) } \\
\hline 2012 & $60 \mathrm{aC}$ & $74 \mathrm{aB}$ & $74 \mathrm{aB}$ & $65 \mathrm{aC}$ & 85 aA & $81 \mathrm{aAB}$ \\
\hline 2013 & $63 \mathrm{aA}$ & $56 \mathrm{bAB}$ & $47 \mathrm{bB}$ & $60 \mathrm{aA}$ & $58 \mathrm{bA}$ & $54 \mathrm{bAB}$ \\
\hline \multicolumn{7}{|c|}{2 weeks (plants per $\mathrm{m}$ ) } \\
\hline 2012 & $61 \mathrm{aC}$ & $87 \mathrm{aB}$ & $83 \mathrm{aB}$ & $81 \mathrm{aB}$ & $100 \mathrm{aA}$ & $87 \mathrm{aB}$ \\
\hline 2013 & $63 \mathrm{aBC}$ & $69 \mathrm{bAB}$ & $56 \mathrm{bc}$ & 76 aA & $73 \mathrm{bAB}$ & $57 \mathrm{bC}$ \\
\hline \multicolumn{7}{|c|}{ RDM (g) } \\
\hline 2012 & $0.63 \mathrm{aBC}$ & $0.47 \mathrm{bC}$ & $0.58 \mathrm{bBC}$ & $0.53 \mathrm{bBC}$ & $0.70 \mathrm{aB}$ & $0.97 \mathrm{aA}$ \\
\hline 2013 & $0.70 \mathrm{aB}$ & 0.94 aA & $0.88 \mathrm{aAB}$ & $0.87 \mathrm{aAB}$ & $0.75 \mathrm{aAB}$ & $0.88 \mathrm{aAB}$ \\
\hline \multicolumn{7}{|c|}{$\mathrm{RV}\left(\mathrm{cm}^{3}\right)$} \\
\hline 2012 & $0.29 \mathrm{aB}$ & $0.24 \mathrm{aB}$ & $0.33 \mathrm{aB}$ & $0.28 \mathrm{aB}$ & $0.37 \mathrm{aB}$ & $0.57 \mathrm{aA}$ \\
\hline 2013 & $0.22 \mathrm{aA}$ & $0.24 \mathrm{aA}$ & $0.22 \mathrm{bA}$ & $0.31 \mathrm{aA}$ & $0.23 \mathrm{bA}$ & $0.35 \mathrm{bA}$ \\
\hline
\end{tabular}

aWithout any treatment. Values followed by the same lower case letter in the columns and upper case letter in the rows within each year and variable are not significantly different at $\mathrm{p} \leq 0.05$ according to Tukey's test. RDM = Root dry mass; RV = Root volume. 
without proper replacement. Thus, according to Ribeiro and Santos (1996), treating seeds only with zinc is not enough to meet the needs of the plant; however, it stimulates root system development, increasing the area of contact of the roots with the soil and offering better plant development. This possibly happens because the first roots from the seeds enriched with zinc are in direct contact with the nutrient (Prado et al. 2007). Studies by Moreira and Zibetti (2011) show that seed treatment with zinc (ajifol, the same source of zinc used in this study) provided longer wheat root compared to the control treatment. This effect is noteworthy since the increase of the root dry mass can be linked to the further development of secondary, thinner roots. According to Nielsen and Barber (1978), thinner root systems have more favorable geometry for the absorption of nutrients in the soil, such as phosphorus. There is a lack of studies on plant root systems as well as on their interaction with seed treatments. In the second year of cultivation, the results were inconsistent because, even though the treatment with zinc showed the largest average result for root volume $\left(0.35 \mathrm{~cm}^{3}\right)$, there was no significant difference between the treatments. This also applies for root dry mass, because the largest one $(0.94 \mathrm{~g})$ achieved with T. asperellum did not differ from that achieved with zinc. Some studies report that excess of zinc in the seeds causes inhibition of root elongation, which is a characteristic parameter of toxicity (Marschner 1995). This was not observed in crambe in the present study. Balardin et al. (2011), when using chemical seed treatments with fipronil + thiophanate methyl + pyraclostrobin and abamectin + thiamethoxam + fludioxonil + mefenoxan + thiabendazole observed higher crambe root volume than in the control treatment. Despite not offering benefits to the second crop, the treatment with zinc has a tendency to provide benefits for the crambe plant.

The thousand grain weight (Table 1) was not affected by the seed treatments and by the interaction between factors; however there was higher (36\%) average weight in $2012(7.13 \mathrm{~g})$ than in $2013(5.21 \mathrm{~g})$. This fact is related to low temperatures (frosts) that partially damaged the leaves and the crop in the flowering stage, which is the time when the crop is more sensitive. Souza et al. (2009) also found no effect of seed treatments on the mass of one hundred grains of soybeans.

The crambe yield achieved in the control treatment was inferior to that obtained with biological treatments and thiamethoxam. Yield results did not differ between the treatments (Table 1) and between both years. These results are due to the higher protective action of biological products and thiamethoxam than the protection provided by treatments with micronutrients. Positive results of isolates of Trichoderma species were reported by Dubey et al. (2011) and Dubey and Singh (2013) in other crops. These results match those obtained by Faria et al. (2003), who carried out a study on cotton, whose seeds were treated with biological agent Trichoderma harzianum and showed performance similar to that of the seeds treated with chemical fungicides carboxin + thiram and carbendazim + thiram. Grain yield in 2012 was higher $(40 \%)\left(1,604 \mathrm{~kg} \cdot \mathrm{ha}^{-1}\right)$ than in $2013\left(1,142 \mathrm{~kg} \cdot \mathrm{ha}^{-1}\right)$, due to climatic conditions as mentioned above. Ludwig et al. (2014) found no effect of the chemical seed treatment with carbendazim on seed yield per crambe plant in a greenhouse. Maciel et al. (2014) observed that the chemical treatment of seeds with pyraclostrobin + thiophanate methyl + fipronil provided larger crambe grain yield. It was the only treatment with better results in comparison to the control treatment.

Crambe oil was considered low in both years and was not influenced by the interaction treatment/year (Table 1). As described above, the correlation between yield and oil as well as the low temperatures in southern Brazil in autumn and winter can harm crops. The biological treatment with T. asperellum resulted in lower (9\%) oil content (21.4\%) than in the control treatment $(23.5 \%)$. There is a lack of information in the scientific literature on the influence of chemical or biological treatments on crambe crops. Amein et al. (2011) demonstrate that there are several options (Bacillus subtilis, Streptomyces griseoviridis) for the non-chemical control of Alternaria brassicicola on brassicas that are comparable in efficiency with chemical seed treatments. Sharma et al. (2010) studied biocontrol with Trichoderma harzianum, Pseudomonas fluorescens, and Bacillus subtilis on Indian mustard (Brassica juncea L.) infected with Alternaria blight and found that the treatment resulted in increased lipid content and protein.

In general, we observed that the contrasting climatic conditions verified each year in tropical regions provided different means of development of pests, diseases, and plant growth, which influenced the dynamics of seed treatments. Seed treatment is a common measure used in the Brazilian agriculture due to intense biotic effects. It depends on climatic conditions and has low input costs. Considering the results presented in this study, we recommend the biological and/or chemical treatment of seeds in tropical conditions. 


\section{CONCLUSION}

Emergence and growth crambe as well as production components and oil in the first year were higher due to the contrast in the agricultural years. In the first year, the chemical treatment with thiamethoxam stood out for germination of plants. Seed treatments did not influence the growth of the aerial parts of the plants, but provided an increase in the root system, especially zinc. Biological (T. asperellum and B. subtilis) and chemical (thiamethoxam) seed treatments led to higher crambe yield when compared to the control treatment; however, the biological treatment with T. asperellum provided less oil.

\section{REFERENCES}

Amein, T., Wright, S. A., Wikström, M., Koch, E., Schmitt, A., Stephan, D., Jahn, M., Tinivella, F. M., Gullino, L., Forsberg, G., Werner, S., Wolf, J. P. C. and Groot, S. P. C. (2011). Evaluation of non-chemical seed treatment methods for control of Alternaria brassicicola on cabbage seeds. Journal of Plant Diseases and Protection, 118, 214-221. http://dx.doi.org/10.1007/BF03356406.

Araujo, F. F. (2013). Inoculação de sementes com Bacillus subtilis, formulado com farinha de ostras e desenvolvimento de milho, soja e algodão. Ciência e Agrotecnologia, 32, 456-462. http:// dx.doi.org/10.1590/S1413-70542008000200017.

Ashraf, M. and Foolad, M. R. (2005). Pre-sowing seed treatment - a shotgun approach to improve germination, plant growth, and crop yield under saline and non-saline conditions. Advances in Agronomy, 88, 223-271. http://dx.doi.org/10.1016/ S0065-2113(05)88006-X.

Balardin, R. S., Silva, F. D., Debona, D., Corte, G. D., Favera, D. D. and Tormen, N. R. (2011). Tratamento de sementes com fungicidas e inseticidas como redutores dos efeitos do estresse hídrico em plantas de soja. Ciência Rural, 41, 1120-1126. http:// dx.doi.org/10.1590/S0103-84782011000700002.

Carneiro, S. M. T. G., Romano, E., Marianowski, T., Oliveira, J. P., Garbin, T. H. S. and Araujo, P. M. (2009). Ocorrência de Alternaria brassicicola em crambe (Crambe abyssinica) no estado do Paraná. Summa Phytopathologica, 35, 154-154. http://dx.doi. org/10.1590/S0100-54052009000200016.

Cunha, R. P., Corrêa, M. F., Schuch, L. O. B., Oliveira, R. C., Abreu Junior, J. S., Silva, J. D. G. and Almeida, T. L. (2015). Diferentes tratamentos de sementes sobre o desenvolvimento de plantas de soja. Ciência Rural, 45, 1761-1767. http://dx.doi. org/10.1590/0103-8478cr20140742.

Dubey, S. C., Bhavani, R. and Singh, B. (2011). Integration of soil application and seed treatment formulations of Trichoderma species for management of wet root rot of mungbean caused by Rhizoctonia solani. Pest Management Science, 67, 1163-1168. http://dx.doi.org/10.1002/ps.2168.

Dubey, S. C. and Singh, B. (2013). Integrated management of major diseases of mungbean by seed treatment and foliar application of insecticide, fungicides and bioagent. Crop Protection, 47, 55-60. http://dx.doi.org/10.1016/j.cropro.2012.12.025.

Empresa Brasileira de Pesquisa Agropecuária (2006). Sistema Brasileiro de Classificação de Solos. Rio de Janeiro: Embrapa; CNPSO.

Faria, A. Y. K., Albuquerque, M. C. F. E. and Cassetari Neto, D. (2003). Qualidade fisiológica de sementes de algodoeiro submetidas a tratamentos químico e biológico. Revista Brasileira de Sementes, 25, 121-127. http://dx.doi.org/10.1590/ S0101-31222003000100019.

Gunatilaka, A. A. L. (2006). Natural products from plant-associated microorganisms: distribution, structural diversity, bioactivity, and implications of their occurrence. Journal of Natural Products, 69, 509-526. http://dx.doi.org/10.1021/np058128n.

Hafeez, F. Y., Safdar, M. E., Chaudhry, A. U. and Malik, K. A. (2004). Rhizobial inoculation improves seedling emergence, nutrient uptake and growth of cotton. Australian Journal of Experimental Agriculture, 44, 617-622. http://dx.doi.org/10.1071/EA03074.

Haider, M. N., Islam, M. R., Aminuzzaman, F. M., Mehraj, H. and Jamal, A. F. M. (2014). Micronutrient and fungicides management practices to control the Alternaria blight of mustard. Journal of Bangladesh Academy ofSciences,38,61-69. http://dx.doi.org/10.3329/jbas.v38i1.20212.

Hossain, M. S. and Mian, H. (2005). Integrated approach for the management of Alternaria blight of cabbage seed crop. Bangladesh Journal of Plant Pathology, 21, 19-23.

Hossen, D. C., Corrêa Júnior, E. S., Guimarães, S., Nunes, U. R. and Galon, L. (2014). Tratamento químico de sementes de trigo. Pesquisa Agropecuária Tropical, 44, 104-109. http://dx.doi. org/10.1590/S1983-40632014000100014. 
Instituto Adolfo Lutz (2008). Métodos físico-químicos para análise de alimentos. $4^{a}$ ed. $1^{a}$ ed. digital. São Paulo: Secretaria de Estado da Saúde.

Ludwig, E. J., Nunes, U. R., Mertz, L. M., Silva, J. R. and Nunes, S. C. P. (2014). Vigor e produção de sementes de crambe tratadas com fungicida, inseticida e polímero. Científica, 42, 271-277. http://dx.doi. org/10.15361/1984-5529.2014v42n3p271-277.

Macagnan, D., Chaves, Z. M. and Café Filho, A. C. (2010). First report of Alternaria brassicicola on Crambe abyssinica in Goiás state, Brazil. Summa Phytopathologica, 36, 260-260. http://dx.doi.org/10.1590/ s0100-54052010000300016.

Maciel, V. A., Araújo D. V., Dias L., Santos, E. P. M. and Fregonese, T. E. F. (2014). Eficiência de fungicidas no controle de doenças na cultura do crambe. Enciclopédia Biosfera, 10, 1451-1463.

Marschner, H. (1995). Mineral nutrition of higher plants. London: Academic Press.

Mattei, D., Silva, T. R. B., Dadazio, T. and Silva, C. A. T. (2013). Seed treatment influence with Carboxin + Thiram to initial development of crambe (Crambeabyssinica Hoechst) in two cropyears. African Journal of Agricultural Research, 8, 2461-2463. http://dx.doi.org/10.5897/ AJAR12.781.

Meena, P.D., Rani, A., Meena, M. C., Sharma, P., Kandpal, B. and Singh, D. (2015). Role of nutrients and lower leaf removal against Alternaria Blight in Indian mustard (Brassica juncea L.). Plant Pathology Journal, 14, 92-96. http://dx.doi.org/10.3923/ppj.2015.92.96.

Mertz, L. M., Henning, F. A. and Zimmer, P. D. (2009). Bioprotetorese fungicidas químicos no tratamento de sementes de soja. Ciência Rural, 39, 13-18. http://dx.doi.org/10.1590/S0103-84782009000100003.

Moers, E. M., Kuhn, O. J., Gonçalves Júnior, A. C., Franzener, G. and Stangarlin, J. R. (2012). Levantamento de doenças na cultura do crambe (Crambe abyssinica Hochst) na região oeste do Paraná. Scientia Agraria Paranaensis, 11, 35-48. http://dx.doi. org/10.18188/1983-1471/sap.v11n1p35-48.

Moreira, G. C. and Zibetti, M. F. B. (2011). Tratamento de sementes de trigo com aminoácidos e fertilizante organomineral. Cultivando o Saber, 4, 109-118.

Munkvold, G. P. (2009). Seed pathology progress in academia and industry. Annual Review of Phytopathology, 47,285-311. http://dx.doi. org/10.1146/annurev-phyto-080508-081916.
Nielsen, M. E. and Barber, S. A. (1978). Differences among genotypes of corn in the kinetics of P uptake. Agronomy Journal, 70, 695-698. http://dx.doi.org/10.2134/agronj1978.0002196 $2007000050001 x$.

Oliveira, S., Tavares, L. C., Lemes, E. S., Brunes, A. P., Dias, I. L. and Meneghello, G. E. (2014). Tratamento de sementes de Avena sativa L. com zinco: qualidade fisiológica e desempenho inicial de plantas. Semina: Ciências Agrárias, 35, 1131-1142. http://dx.doi.org/10.5433/1679-0359.2014v35n3p1131.

Pitol, C., Broch, D. L. and Roscoe R. (2010). Tecnologia e produção: crambe 2010. Maracaju: Fundação MS.

Prado, R. M., Frade Junior, E. F., Mouta, E. R., São João, A. C. G., Costa, R. S. S. and Costa, R. S. S. (2007). Crescimento inicial e estado nutricional do trigo submetido à aplicação de zinco via semente. Revista de la Ciencia del Suelo y Nutrición Vegetal, 7 , 22-31. http://dx.doi.org/10.4067/S0718-27912007000200003.

Ribeiro, N. D. and Santos, O. S. (1996). Aproveitamento do zinco aplicado na semente na nutrição da planta. Ciência Rural, 26, 159-165. http://dx.doi.org/10.1590/S0103-84781996000100030.

Sharma, A. and Johri, B. N. (2003). Growth promoting influence of siderophore-producing Pseudomonas strains GRP3A and PRS9 in maize (Zea mays L.) under iron limiting conditions. Microbiological Research, 158, 243-248. http://dx.doi. org/10.1078/0944-5013-00197.

Sharma, S., Singh, J., Munshi, G. D. and Munshi, S. K. (2010). Effects of biocontrol agents on lipid and protein composition of Indian mustard seeds from plants infected with Alternaria species. Archives of Phytopathology and Plant Protection, 43, 589-596. http://dx.doi.org/10.1080/03235400801972350.

Souza, L. C. F., Zanon, G. D., Pedroso, F. F. and Andrade, L. H. L. (2009). Teor de proteína e de óleo nos grãos de soja em função do tratamento de sementes e aplicação de micronutrientes. Ciência e Agrotecnologia, 33, 1586-1599. http://dx.doi.org/10.1590/S1413-70542009000600018.

Yagi, R., Simili, F. F., Araújo, J. C., Prado, R. M., Sanchez, S. V., Ribeiro, C. E. R. and Barretto, V. C. M. (2006). Aplicação de zinco via sementes e seu efeito na germinação, nutrição e desenvolvimento inicial do sorgo. Pesquisa Agropecuária Brasileira, 41, 655-660. http://dx.doi.org/10.1590/ s0100-204X2006000400016. 